\title{
THE ENDOWMENT FUND FOR THE SUPPORT OF THE JOURNAL OF DENTAL RESEARCH
}

\author{
SEVENTH REPORT
}

WILLIAM J. GIES

Subscriptions to the endowment fund for the support of the JourNaL of Dental Research have been received, since the publication of the sixth report (vol. II, p. 325), from the twenty-one additional contributors named below:

\section{NAMES AND ADDRESSES OF NEW CONTRIBUTORS}
Lewellys F. Barker
1035 North Calvert Street, Baltimore, Md.
John P. Buckley.
1550 Hayworth Avenue, Los Angeles, Calif.
Chas. E. B. Chase..........29 Commonwealth Avenue, Boston, Mass.
Martin Dewey............25 East Washington Street, Chicago, Ill.
Martin B. Dill...........283 Dartmouth Street, Boston, Mass.
George Evans, Sr..........55 West 39th Street, New York City
A. C. Fones............ 10 Washington Avenue, Bridgeport, Conn.
Charles Goldstein..........944 Aldus Street, New York City
Gladstone Goode...........576 Fifth Avenue, New York City
George A. Hull...........158 West 73rd Street, New York City
Olin Kirkland.............. Montgomery, Ala.
Alfred E. Knight..........80 Boylston Street, Boston, Mass.
John S. Marshall...........2912 Pine Avenue, Berkeley, Calif.
Robert T. Moffatt.........520 Beacon Street, Boston, Mass.
Frederick B. Noyes.........122 South Michigan Avenue, Chicago, Ill.
Alfred Owre.............. University of Minnesota, Minneapolis, Minn.
A. G. Roitman...........32 Central Square, East Boston, Mass.
Harry B. Shuman.............128 Newbury Street, Boston, Mass.
Leo Stern...............270 Park Avenue, New: York City
Benjamin Tishler.........360 Commonwealth Avenue, Boston, Mass.
Justin D. Towner..........1206 Exchange Building, Memphis, Tenn.

NAMES AND ADDRESSES OF FUNDORS LISTED IN THE GENERAL REPORT FOR 1919 [VOL. I, P. (39)], WHO HAVE ALSO MADE CONTRIBUTTONS FOR THE YEAR 1920

Louise C. Ball............. 755 Park Avenue, New York City

Leland Barrett...........220 West 98th Street, New York City

Oscar J. Chase, Jr.........17 East 38th Street, New York City

Sebert E. Davenport.........51 West 47th Street, New York City

S. E. Davenport, Jr.........51 West 47 th Street, New York City

William J. Gies............437 West 59th Street, New York City

A. I. Hadley.............125 Marlborough Street, Boston, Mass. 


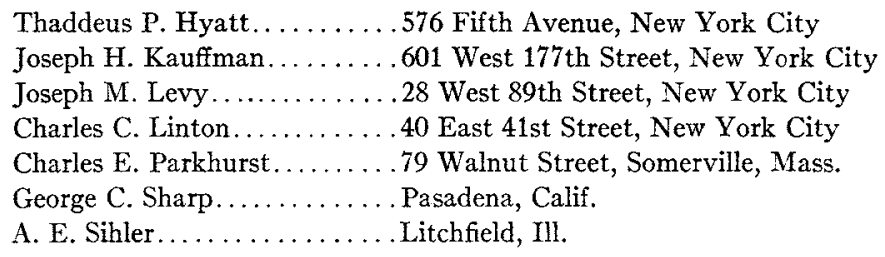

Amount paid by the total number of contributors (194) to date

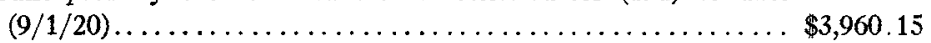

Amount of payments recorded in the sixth report (vol. II, p. 325) .. $3,654.15$

Amount of payments received since the publication of the sixth

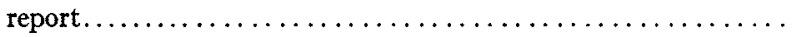

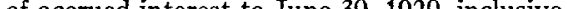

.

Total amount of the fund........................... 4,074.10

Expenditures from the fund.......................... None

Total amount of the fund invested in United States securities, at rates of interest ranging from 4 per cent to 6 per cent....... 4,000.00

It is a very great pleasure to call special attention to the generosity of the dental business men and organizations named below, who have contributed effectively to the permanent support of this JouRNAL without qualification, condition or reservation, and who have shown, by the cordiality of their specific approval, that they wish to encourage and foster the development of independent research and scientific journalism in dentistry.

Albodon Company, 7 West 45 th Street, New York City

Borine Manufacturing Company, 551 West 42nd Street, New York City

A. R. Deacon, Secretary of the Lambert Pharmacal Company, 2101 Locust Street, St. Louis, Mo.

J. W. Ivory Dental Specialties, 21 North 13th Street, Philadelphia, Pa.

Lambert Pharmacal Company, 2101 Locust Street, St. Louis, Mo.

Lincoln Dental Manufacturing Company, 1600 Chestnut Street, Philadelphia, Pa.

Oakland Chemical Co., 10 Astor Place, New York City

Philadelphia Dental Laboratory, Philadelphia, Pa.

Prophylactic Tooth Powder, Inc., 38 East 61st Street, New York City

A complete list of the contributors to this fund, to the end of the year 1919, was published in the section of general matter, including the title page, for volume I. The first two supplementary lists for 1920 were published on pages 195 and 325 of this volume.

Contributions to this permanent endowment fund, in any amounts, are invited from all who may be interested in the relfare and continuing success of this JOURNAL. 